standing of the general concepts of poetry, or to many specific features of the work. Zelinsky's discussion centers on both the well-known issues essential for understanding Romanticism and on the less tangible philosophical and aesthetic tenets of the somewhat esoteric Russian theory and practice of this trend. Naturally, he starts with such general notions as the theory of poetry as prophecy and the role of inspiration. The discussion of religious and spiritual ecstasy, passion, suffering, and so forth takes us to the more specific situation of Russia and the individual Russian Romantics.

It is quite natural for the author to follow the German and Russian tradition in dealing with Romanticism. The absence of a discussion of Evgenii Onegin, for example, seems to indicate that Zelinsky follows the traditional view, taking for granted that Onegin has little to do with Romanticism. No mention is made of the view argued by Ettore Lo Gatto ("L'Onegin come diario lirico di Pushkin," in Bruno Becker Festschrift) that the lyrical stream in Onegin, representing the poet's individual comments and digressions, links the work with Romanticism in a very interesting way. Zelinsky occasionally refers to representatives of other schools, but mainly on matters of detail rather than on general approach. Thus, on the whole, the thematic aspect is given much more attention than the problem of the formal revolution initiated by the Romantic trend. Some of the formal achievements of individual writers are analyzed in fine detail, however.

One of the book's most serious methodological difficulties is caused by the rather anachronistic tendency to follow the Aristotelian tradition of dividing all literary creation into three categories: Lyrik, Epik, Dramatik. Applied mechanically to all trends of Romanticism, this formula is bound to lead to inconsistencies and compromises, for example, the analysis of lyric poems to illustrate problems, discussed for some reason in the chapter on Epik. (Lermontov's Zvuki and Tiutchev's and Mandelstam's Silentium are given as illustrations of such phenomena as Sehnsucht nach dem schweigenden Urgrund and Rückwendung des Menschen in die Tiefe der eigenen Seele, as if they were examples of the "epic" descriptive genre.) Nevertheless, the actual discussion of these and other problems is competent and objective, and is supported in places by appropriate extensions into the realm of modern poetry (Pasternak, Mandelstam, Vinokurov, and so forth).

This study is published in the prestigious series, Slavistische Forschungen, edited by Reinhold Olesch. It follows, of course, the old and useful tradition of supplying not only a name index but also separate subject and chronological indexes.

Z. FolejeWsKI

University of Ottawa

\title{
THE LITERARY BALLAD IN EARLY NINETEENTH-CENTURY RUSSIAN
} LITERATURE. By Michael R. Katz. London: Oxford University Press, 1976. xiv, 248 pp. $£ 10.00 . \$ 22.00$.

The title of this book does not do it justice; in addition to a thorough investigation of the Russian ballad in the early nineteenth century, the book contains an extensive survey of the history of the genre of the ballad in Western Europe (England, Germany, and France), as well as a short history of the Russian literary epithet in the eighteenth and early nineteenth centuries. The author also includes theoretical discussions dealing with the concepts of "ballad" and "epithet," and provides appendixes containing statistical data on the types and frequency of epithets in Russian and Western folk ballads and literary ballads. Because Zhukovskii is the major balladist in Russian literature, his work dominates the discussion. In addition, there are chapters dealing with Zhukovskii's "imitators," particularly Kozlov, Katenin, and Meshchevskii, two chapters on 
the balladic creations of Pushkin and Lermontov, and a chapter surveying the development of the genre in Russian literature in the 1790s.

The topic has been extremely well researched. The author is familiar with the original works, unpublished manuscripts, and early versions of the ballads discussed, and is conversant with existing critical essays, memoirs, and other bibliographical material related to the topic. The wealth of material presented is overwhelming and makes the book an excellent source of factual information on the topic.

While Zhukovskii's ballads have received much attention from critics, those of Murav'ev and other eighteenth-century poets have been neglected. Mr. Katz takes a close look at the ballad in Russian literature at the turn of the eighteenth century and traces its emergence and development to Western sources. His research convincingly proves that Soviet literary historians' claims, which attribute the development of the ballad genre to native folkloric sources, are unfounded. He also takes exception to the commonly held view that Zhukovskii's ballads show a marked influence of Russian folklore: taking Zhukovskii's epithets as a testing ground, Mr. Katz argues that the coincidence between them and epithets found in folk ballads is insufficient grounds for claiming a direct influence. In general, Mr. Katz's discussion of Zhukovskii's use of the epithet is interesting, although the substance of his disagreement with Gukovskii and Gukovskii's opponent, Petushkov, is not always clear. Despite Gukovskii's and Petushkov's different approaches, Mr. Katz points out (p. 92) that their conclusions are "remarkably close." Dissatisfied with their methods, Mr. Katz undertakes his own analysis of Zhukovskii's epithets and comes to the following conclusion: "The originality of Zhukovsky's epithets, then, resides in their total subjectivity and in the complex interrelationship between their applicability and their indeterminateness" (pp. 99-100), which sounds "remarkably close" to Gukovskii's and Petushkov's opinions. The disproportionately long discussion in this chapter on the nature of the epithet in general and on its development in Russian literature before Zhukovskii should have been placed in the appendix.

The author's enthusiasm for his subject occasionally causes him to exaggerate the importance of the ballad genre in Russian literature. Thus he states that the ballad was "the most influential" form of poetry (p.36) and attained "the popularity and the literary status which the ode had enjoyed during the mid-eighteenth century" (p. 38). Statistically and objectively speaking, the elegy and the poema were much more important, and recent research has revealed that the spiritual ode, in all its variant forms, was perhaps the most prolific genre in Russian poetry of the second half of the eighteenth century and eventually led to the emergence of lyrical poetry with its subjective tone and vocabulary (see Alexander Levitsky, "The Spiritual Ode In Russian Eighteenth-Century Poetry" [Ph.D. diss., University of Michigan, 1977]).

Throughout the book, Mr. Katz emphasizes the point that Zhukovskii's ballads were "an extension of his lyrical poetry" (p. 40). This is certainly true, but it does not invalidate other critics' opinions (which Mr. Katz totally rejects), namely, Galich's view that Zhukovskii's ballads were an objectivization of the poet's inner states, or Izmailov's suggestion that Zhukovskii sympathized with human suffering and man's submission to fate and sought to create an ideal dream world.

The chapter, "Zhukovsky's Imitators," contains a great deal of interesting material. Here Katenin is shown to be more of an imitator than an opponent of Zhukovskii. In discussing the two translations of Bürger's "Lenore," by Katenin and by Zhukovskii, Mr. Katz omits the most striking difference: the word "Gesindel" in the original was rendered as "svoloch"” by Katenin and as "legkie teni" by Zhukovskii. Katenin's ballad "Leshii" is appraised positively by Mr. Katz, although psychologically and stylistically it is contrived and cannot really be called a folk ballad. The inclusion of Meshchevskii's work in this chapter does not seem justified in view of his obscurity. 
Another questionable point is Mr. Katz's view of parody. Can one really consider "Svetlana" to be "Bürger's 'Lenore' and Zhukovsky's 'Lyudmila' turned upside down, mocked, or parodied" (p. 59) ? It would appear that the unexpected twist at the end of the story reminded Mr. Katz of similar parodic twists in Pushkin's Tales of Belkin, and led him to conclude that this too was a parody. The fact is that there are no parodic elements, either in style or in intent, discernible in Zhukovskii's tale; the "happy ending" was an afterthought (the original draft had a tragic denouement). On the other hand, elsewhere in his book, Mr. Katz fails to recognize parody in Pushkin's "Chernaia shal" (p. 142), although its tone and vocabulary are so unlike Pushkin that it prompted a parody by A. K. Tolstoi.

My final critical remark concerns the idea of Zhukovskii's originality. It seems to me that one is playing with the semantics of the word "original" when one ascribes it to translations. Zhukovskii's ballads are talented and imaginative reworkings and adaptations but certainly not completely original pieces, as $\mathrm{Mr}$. Katz indirectly admits when he states that "Svetlana" is one of the poet's "most original works" (p. 59).

Among some minor points, $I$ find it amusing to see Leon Trotsky's name listed alongside "other critics," such as Pushkin and Belinskii (p. 74), but perhaps it was Mr. Katz's intention to amuse us. Misprints are amazingly few as are misspellings ("xozajka" instead of xozjajka occurs twice, the Ukrainian title of the song on p. 141 is misspelled, and the title of Shakhovskoi's comedy "Urok koketkam" is consistently given as "Urok koketam").

I have been deliberately exhaustive in my "negative" criticism in order to illustrate how relatively few faults I could find with this fine and well-written book. It was a pleasure to read it, and I can only recommend it to students of Russian poetry.

Assya Humesky

University of Michigan

DOSTOEVSKY: THE LITERARY ARTIST. By Erik Krag. Translated from the Norwegian by Sven Larr. Oslo and Atlantic Highlands, N.J.: Universitetsforlaget and Humanities Press, 1976 [1962]. 317 pp. \$20.00, paper.

FROM GOGOL TO DOSTOEVSKY: JAKOV BUTKOV, A RELUCTANT NATURALIST IN THE 1840'S. By Peter Hodgson. Munich: Wilhelm Fink Verlag, 1976. x, 190 pp. DM 28, paper.

The appearance of the Academy edition of Dostoevsky's works has created a watershed in Dostoevsky scholarship. Recent books which have not had the benefit of the information contained in the introductory articles and commentaries of the Academy edition will show some gaps of which readers will be acutely aware. Krag's excellent work is in this category. Even more unfortunate, his work has not been updated to include recent Western scholarship: the names of Dominique Arban, Maximilian Braun, Joseph Frank, Robert L. Jackson, Ralph E. Matlaw, and Edward Wasiolek, to name but a few, are missing from his index of authors. Save for this deficiency, Krag's Dostoevsky would be well suited as a manual for the professor who teaches Dostoevsky but is not himself a Dostoevsky scholar: it contains a well-selected body of information on the biographical, historical, ideological, and literary background of Dostoevsky's works; it reconstructs the genesis of each major work carefully, using all available sources; it summarizes existing interpretations objectively and concisely; and it presents many of the problems connected with the philosophical and aesthetic content of each work clearly and judiciously. Krag's mastery of his material is evident at all times. On the other hand, Krag's book is not remarkable for depth of empathy, 